Sel'skoye khozyaystvo za rubezhom - Agriculture Abroad, 6, 2-7 [in Russian].

11. Mazur, H.A., Polovyi, V.M. \& Lavruk, M.M. (2005). Vplyv vapnuvannya i tryvaloho udobrennya na vrozhaynist' kul'tur sivozminy v umovakh zakhidnoho Polissya [Influence of liming and prolonged fertilization on crop yields of crop rotation in the western Polesie]. Naukovyy visnyk Natsional' noho ahrarnoho universytetu - Scientific Bulletin of the National Agrarian University, 91, 60-65 [in Ukrainian].

12. Kulakovskaia, T.N. (1974). Mineral'nyye udobreniya i plodorodiye pochv [Mineral fertilizers and soil fertility]. Plodorodiye pochoy $i$ urozhay [Soil fertility and yield]. Vil'njus: Periodika [in Russian].
13. Sypko, A.O., Strilets, O.P. \& Sinchuk, H.A. (2013). Vplyv vapnuvannya na vmist humusu chornozemi typovomu v umovakh pivnichno-skhidnoho Lisostepu [The effect of liming on the content of humus of black soil typical in the conditions of the northeastern foreststeppe]. Visnyk ahrarnoyi nauky - Bulletin of agrarian science, 5, 19-22 [in Ukrainian].

14. Sypko, A.O. \& Honcharuk, H.S. (2014). Vidtvorennya vmistu humusu u slabo-kyslomu siromu lisovomu grunti za khimichnoyi melioratsiyi v umovakh Pravoberezhnoho Lisostepu [Reproduction of humus content in slightly acidic gray forest soil by chemical reclamation in the Right-bank Forest Steppe]. Visnyk ahrarnoyi nauky - Bulletin of agrarian science, 1, 55-58 [in Ukrainian].

Стаття надійшла до редакції журналу 24.01.2020

\title{
USE OF TANK MIXTURES FOR POTATO PLANTS PROTECTION FROM PHYTOPHTHORA INFESTANS AND ALTERNARIA SOLANI DISEASE AGENTS
}

\author{
S. Fedorchuk ${ }^{1}$, T. Klymenko ${ }^{1}$, V. Radko ${ }^{1}$, O. Trembitska ${ }^{1}$, M. Lisovyy ${ }^{2}$ \\ ${ }^{1}$ Поліський національний університет \\ ${ }^{2}$ Національний університет біоресурсів і природокористування України
}

\begin{abstract}
На сьогодні однією із важливих проблем щодо отримання високих стабільних урожаїв картоплі є своєчасне вжиття відповідних заходів проти хвороб і шкідників. Незначний розмір земельних ділянок та неякісний садивний матеріал, відсутність дотримання сівозмін призводить до накопичення і поширення збудників хвороб, зокрема Phytophthora infestans (Mont.) De Bary ma Alternaria solani, які без застосування засобів захисту можуть знизити врожайність культури до 60\% і більше. Доведено, що найефективнішу дію проти ураження листків картоплі фітофторозом проявила суміш хімічного препарату Антракол та регулятора росту рослин Гумісол. Встановлено, що оптимальним було поєднання хімічного препарату Антракол із РРР Гумісол, де на різних за стійкістю сортах картоплі ураженість рослин у фазу цвітіння (максимальний розвиток патогенів) збудниками становила: Phytophthora infestans - 1,4-24,6\%, a Alternaria solani $-6,8-22,2 \%$.
\end{abstract}

Ключові слова: картопля, сорт, збудники хвороб, регулятор росту рослин, хімічний та біологічний препарати.

Complex systems of protection of crops against potato diseases have been developed during 60-80s of the past century. The necessity to combine preparations for plants protection against various groups of phytopathogens (insects, disease agents and weed plants) into

(C) S. Fedorchuk, T. Klymenko, V. Radko, O. Trembitska, M. Lisovyy, 2020 one integrated system of measures was taken as a main principle [1]. Factors that influence decrease of potato damage evidence complex nature of disease manifestation which, in its turn, requires systematic protection [2].

Complex combination of protection of plants was built on the basis of zonal approach, specifically, with consideration to 
types of disease agents and other pathogenic agents that damage potato in given agricultural climatic zone [3, 4]. They are based on chemical method. Plantations were treated during relative phenological phases of potato or calendar periods of phytopathogens appearance regardless of their actual number and display during the given season or period. Main principle of complex systems is a necessity to combine various methods of protection of given crop from different groups of phytopathogens into single system of measures and it has been preserved in integrated, intensive and other technologies of crops growing, nevertheless, it has changed significantly due to development and improvement of chemical, agrotechnical, biological and other methods of protection $[5,6]$.

Authors like Razkevych M.P. and Podberezko I.M. [7] in their scientific works mention, that use of chemical preparations Tanos and Rydomil Gold mixed with growth regulators BTF + Potatin guarantee the highest level of protection against Alternaria blight and by highest we mean 50-56\%. Combination of these preparations allows helps to enhance harvest growth by $7.7 \mathrm{t} / \mathrm{ha}$, net income amounts to appr. $1799 \mathrm{UAH} / \mathrm{ha}$. Accumulative combination of preparation with growth regulator allows to decrease chemical's usage rate by $20 \%$ without damage to protective effect that guarantees dynamic reduction of pathological processes and increase of harvest yield, however, with decrease of pesticides environmental load. Thus, accumulative combination of preparations in tank mixtures does not minimize their fungicidal and insecticidal activity against various plant pests herewith does not cause phytotoxicity of potato plants. Technical efficiency of the use of tank mixtures of pesticides was $86.6-87.8 \%$ and harvest growth of potato tubers of the middleearly variety of potato Dublinska yuvileyna was 135-157 centner/ha [7, 8].

Aim of research - influence of combined use of growth regulators, chemical and biological preparations on different by resistance potato varieties under field conditions against Phytophthora infestans (Mont.) de Bary and Alternaria solani disease agents.

\section{MATERIAL AND METHODS}

Our research was carried out on the research field of Zhytomyr National University of Agriculture and Ecology (village Velyka Gorbasha Cherniakhiv district Zhytomyr region) in 2013-2017. We studied effect of preparations on varieties different by resistance to disease: Bonus (relatively resistant), Vedruzka (medium resistant) and Glazurna (susceptible).

We used the following preparations: chemical Antrakol w.p., biological Phytosporyn M, p. and growth regulator Humisol, p. Potato plants were sprayed during vegetation period by stages of plant development - sprout, budding and flowering.

Experiment variants included:

1. Control (treatment with water)

2. Humisol, p. (2 l/t) + Antrakol, w.p. (1.5 kg/ha)

3. Phytosporyn - M, p. $(3.0 \mathrm{~kg} / \mathrm{ha})+$ Humisol, p. (2 l/t)

4. Antrakol, w.p. (1.5 kg/ha) + Phytosporyn $-\mathrm{M}$, p. (3.0 kg/ha).

In tank mixtures rate of each preparation usage was decreased by $25 \%$.

Sections in the field were located based on randomization method of Dospekhov B.A. [9] with 4-fold recurrence.

Records were kept based on standard methods, technology of potato growing standard for Polissya zone [10].

Statistical treatment was done according to the method of Dospekhov B.A. [9].

\section{RESULTS AND RESEARCH}

In laboratory conditions we have determined the best preparations among groups of chemical, biological and growth regulators and have investigated their combined usage for varieties of potato different by resistance in field conditions of our research. Results of research are given in the Table 1.

Plants were mostly damaged by the pathogenic agent Phytophthora infestans during flowering stage and, especially, control variant (treatment with water). Damage of susceptible variety Glazurna during this variant of experiment was $75.0 \%$, medium resistant 
Table 1

Influence of combined use of preparations on damage of different by resistance potato plants by Phytophthora infestans under field conditions, \% (average for 2013-2015)

\begin{tabular}{|c|c|c|c|c|c|c|c|c|c|}
\hline \multirow{3}{*}{ Experiment variant } & \multicolumn{9}{|c|}{ Potato varieties } \\
\hline & \multicolumn{3}{|c|}{$\begin{array}{c}\text { Bonus } \\
\text { (relatively resistant) }\end{array}$} & \multicolumn{3}{|c|}{$\begin{array}{l}\text { Vedruzka (medium } \\
\text { resistant) }\end{array}$} & \multicolumn{3}{|c|}{ Glazurna (susceptible) } \\
\hline & s & $\mathrm{b}$ & f & s & $\mathrm{b}$ & f & $\mathrm{s}$ & $\mathrm{b}$ & f \\
\hline Control (treatment w/water) & 0.3 & 1.7 & 3.5 & 3.9 & 15.3 & 25.5 & 10.3 & 45.6 & 75.0 \\
\hline $\begin{array}{l}\text { Humisol p. }(21 / \mathrm{t})+ \\
\text { Antrakol, w.p. }(1.5 \mathrm{~kg} / \mathrm{ha})\end{array}$ & 0.2 & 1.0 & 1.4 & 2.8 & 8.4 & 12.2 & 4.2 & 20.8 & 24.6 \\
\hline $\begin{array}{l}\text { Phytosporyn - M, p. } \\
(3.0 \mathrm{~kg} / \mathrm{ha})+\text { Humisol, p. } \\
(2 \mathrm{l} / \mathrm{t})\end{array}$ & 0.3 & 1.4 & 2.8 & 3.4 & 10.6 & 16.1 & 5.3 & 22.4 & 30.5 \\
\hline $\begin{array}{l}\text { Antrakol, w.p. }(1.5 \mathrm{~kg} / \mathrm{ha})+ \\
\text { Phytosporyn- M, p. } \\
(3.0 \mathrm{~kg} / \mathrm{ha})\end{array}$ & 1.3 & 1.2 & 1.8 & 3.2 & 8.8 & 14.2 & 4.4 & 21.0 & 26.4 \\
\hline $\mathrm{SSD}_{0.5}$ & & & 0.2 & & & 1.2 & & & 2.6 \\
\hline
\end{tabular}

Note: $\mathrm{s}$ - sprout, $\mathrm{b}$ - budding, $\mathrm{f}$ - flowering.

Vedruzka $-25.5 \%$ and relatively resistant Bonus - $3.5 \%$.

On the other hand, combination of preparations has significantly changed development of the agent. When chemical preparation Antrakol was used with growth regulator Humisol, number of damaged plants of Glazurna variety was reduced to $24.6 \%$, Vedruz$\mathrm{ka}-12.2 \%$, Bonus $-1.4 \%$. It was the most effective mixture among investigated preparations in the experiment.

Mixture of biological preparation and growth regulator turned out least effective. Use of Phytosporyn - $\mathrm{M}$ and growth regulator Humisol reduced damage of potato plant to $30.5 \%$ for Glazurna variety, $16,1 \%$ for Vedruzka variety and 3,4\% for Bonus variety.

This way, when tank mixture of chemical, biological preparations and growth regulators was used, the best effect on damage of potato plants by late blight disease of potato produced mixture of chemical preparation Antrakol and growth regulator Humisol.

Tank mixture of studied preparations was also effective against disease agent Alternaria solani (table 2). Besides, plants were mostly damaged during flowering stage. If damage of plants during control variant was 50,0\%, upon use of preparations Antrakol and Humisol these figures decreased for Glazurna variety to $22.0 \%$, Vedruzka $-17.8 \%$ and Bonus variety $-6.8 \%$. It should be mentioned that as in the previous case it was the most effective tank mixture against Alternaria solani.

Difference in efficiency in comparison to previous variant was determined during combined use of the chemical Antrakol and biological preparation Phytosporyn - M. Damage of plants for Glazurna variety was $26.0 \%$, Vedruzka $-18.4 \%$ and Bonus variety $-7.2 \%$. Difference in plants damage by potato varieties was $0.4-4.0 \%$ with $\mathrm{HIP}_{0.5} 0.9-2.8 \%$.

Least effective was mixture of biological preparation Phytosporyn - M and growth regulator Humisol. Damage of plants increased and came up to $32.4 \%$ for Glazurna variety, $21.2 \%$ for Vedruzka variety and $7.6 \%$ for Bonus variety.

Thus, mixture of preparation Antrakol and growth regulator Humisol was the most effective.

Thus, when growth regulator, chemical and biological preparations were used against Phytophthora infestans (Mont.) de Bary and 
Table 2

Influence of combined use of preparations on damage of different by resistance potato plants by Alternaria solani under field conditions, \% (average for 2013-2015)

\begin{tabular}{|c|c|c|c|c|c|c|c|c|c|}
\hline \multirow{3}{*}{ Experiment variant } & \multicolumn{9}{|c|}{ Potato varieties } \\
\hline & \multicolumn{3}{|c|}{$\begin{array}{c}\text { Bonus } \\
\text { (relatively resistant) }\end{array}$} & \multicolumn{3}{|c|}{$\begin{array}{c}\text { Vedruzka } \\
\text { (medium resistant) }\end{array}$} & \multicolumn{3}{|c|}{ Glazurna (susceptible) } \\
\hline & s & $\mathrm{b}$ & f & $\mathrm{s}$ & $\mathrm{b}$ & $\mathrm{f}$ & $\mathrm{s}$ & $\mathrm{b}$ & $\mathrm{f}$ \\
\hline Control (treatment w/water) & 3.5 & 5.7 & 9.5 & 10.5 & 17.3 & 25.7 & 18.1 & 35.5 & 50.0 \\
\hline $\begin{array}{l}\text { Humisol, p. }(2 \mathrm{l} / \mathrm{t})+ \\
\text { Antrakol, w.p. }(1.5 \mathrm{~kg} / \mathrm{ha})\end{array}$ & 2.6 & 4.5 & 6.8 & 7.5 & 10.8 & 17.8 & 10.6 & 18.4 & 22.2 \\
\hline $\begin{array}{l}\text { Phytosporyn - M, p. } \\
(3.0 \mathrm{~kg} / \mathrm{ha})+\text { Humisol, p. } \\
(2 \mathrm{l} / \mathrm{t})\end{array}$ & 2.8 & 4.9 & 7.6 & 8.8 & 13.4 & 21.2 & 13.2 & 24.2 & 32.4 \\
\hline $\begin{array}{l}\text { Antrakol, w.p. }(1.5 \mathrm{~kg} / \mathrm{ha})+ \\
\text { Phytosporyn }-\mathrm{M}, \mathrm{p} . \\
(3.0 \mathrm{~kg} / \mathrm{ha})\end{array}$ & 2.7 & 4.6 & 7.2 & 7.9 & 11.5 & 18.4 & 11.8 & 20.8 & 26.5 \\
\hline $\mathrm{SSD}_{0.5}$ & & & 0.9 & & & 1.5 & & & 2.8 \\
\hline
\end{tabular}

Note: $\mathrm{s}$ - sprout, $\mathrm{b}$ - budding, $\mathrm{f}$ - flowering.

Alternaria solani disease agents mixture of preparation Antrakol and growth regulator Humisol was the most effective, when damage of different by resistance potato varieties by Phytophthora infestans was $1.4-24.6 \%$ and by Alternaria solani - 6.8-22.2\%.

\section{CONCLUSION}

When tank mixtures were used in the system of potato planting protection against
Phytophthora infestans (Mont.) de Bary and Alternaria solani disease agents the most effective was combination of the chemical preparation Antrakol and growth regulator Humisol, when damage of different by resistance varieties of potato at blooming stage (maximum development of pathogenic agents) by Phytophthora infestans was $1.4-24.6 \%$ and by Alternaria solani $6.8-22.2 \%$.

\section{ЛІТЕРАТУРА}

1. Иванюк В.Г. Защита картофеля от болезней, вредителей и сорняков / В.Г. Иванюк, С.А. Банадысев, Г.К. Журомский. - Минск: Белпринт, 2005. $-696 \mathrm{c}$.

2. Иванюк В.Г. Влияние сроков опрыскиваний фунгицидами на поражение картофеля фитофторозом и альтернариозом / В.Г. Иванюк, Д.А. Брукиш // Защита растений: Сб. науч. тр. БНИИЗР. - 1998. - Вып. 21. - С. 132-143.

3. Ласточкин В.И. Комплексное применение биопрепаратов и фунгицидов против фитофтороза картофеля / В.И. Ласточкин // Актуальные проблемы защиты картофеля, плодовых и овощных культур от болезней, вредителей и сорняков: Материалы Междунар. науч.-практ. конф. - Самохваличи; Минск, 2005. - С. 132-135.

4. Activation of defence responses to Phytophthora infestans in potato by BABA / T. Bengtsson, A. Ho- lefors, J. Witzell et al. // Plant Pathol. - 2014. Vol. 63(1). - P. 193-202. DOI: 10.1111/ ppa.12069

5. Genetic analysis of Phytophthora infestans populations in the Nordic European countries reveals high genetic variability / M.B. Brurberg, A. Elameen, V.H. Lea et al. // Fungal Biology. - 2011. - Vol. 115. - P. 335-342. DOI: 10.1016/j.funbio.2011.01.003

6. Simulation of potato late blight in the Andes. I: modification and parameterization of the LATEBLIGHT model / J. L. Andrade-Piedra, R.J. Hijmans, G.A. Forbes et al. // Phytopathology. - 2005. Vol. 95(10). - P. 1191-1199. DOI: 10.1094/phyto95-1191

7. Знаменсъжий О.П. Перспективи застосування фунгіцидів та їх сумішей з біологічно активними препаратами для захисту картоплі від хвороб / О.П. Знаменський, М.П.Разкевич, I.М. Подберез- 
ко // Картоплярство України. - 2009. - № 5/6. - C. 44-47.

8. Andrivon D. Development of natural late blight epidemics in pure and mixed plots of potato cultivars with different levels of partial resistance / D. Andrivon, J.M. Lucas, D. Ellissèche // Plant
Pathol. - 2003. - Vol. 52(5). - P. 586-594. DOI: $10.1046 / \mathrm{j} .1365-3059.2003 .00882 . x$

9. Доспехов Б.А. Методика полевого опыта / Б.А. Доспехов. - М.: Колос, 1985. - 336 с.

10. Трибель С.О. Методики випробування і застосування пестицидів / С.О. Трибель та ін.; за ред. С.О. Трибеля. - К.: Світ, 2001. - 448 с.

\section{REFERENCES}

1. Ivanyuk, V.G., Banady`sev, S.A. \& Zhuroms`kij, G.K. (2005). Zashhita kartofelya ot boleznej, vreditelej $i$ sornyakov sorniakov [Protection from diseases, pests and weed plants]. Minsk: Belprint [in Russian].

2. Ivanyuk, V.G. \& Brukish, D.A. (1998). Vliyanie srokov opry`skivanij fungicidami na porazhenie kartofelya fitoftorozom i al ternariozom [Influence of period spraying with fungicides on potato damage by late blight disease of potato and Alternaria blight]. Zashhita rastenij - Plant protection 21, 132-143 [in Russian].

3. Lastochkin, V.I. (2005). Kompleksnoe primenenie biopreparatov i fungicidov protiv fitoftoroza kartofelya [Complex use of biologically-active preparations and fungicides against late blight disease of potato]. Aktual'ny'e problemy' zashhity' kartofelya, plodovy'x $i$ ovoshhny'x kul'tur ot boleznej, vreditelej $i$ sornyakov [Actual problems of the protection of potatoes, fruit and vegetable crops from diseases, pests and weeds]. Samohvalichi; Minsk [in Russian].

4. Bengtsson, T., Holefors, A., Witzell, J. \& et al. (2014). Activation of defence responses to Phytophthora infestans in potato by BABA. Plant Pathol, 63(1), 193-202. DOI: 10.1111/ppa.12069 [in English].

5. Brurberg, M.B., Elameen, A., Lea, V.H. \& et al. (2011). Genetic analysis of Phytophthora infestans populations in the Nordic European countries reveals high genetic variability. Fungal Biology, 115,
335-342. DOI: 10.1016/j.funbio.2011.01.003 [in English].

6. Andrade-Piedra, J.L., Hijmans, R.J., Forbes, G.A. \& et al. (2005). Simulation of potato late blight in the Andes. I: modification and parameterization of the LATEBLIGHT model. Phytopathology, 95(10), 1191-1199. DOI: 10.1094/phyto-95-1191 [in English].

7. Znamenskyi, O.P., Razkevych, M.P. \& Podberezko, I.M. (2009). Perspektyvy zastosuvannia funhitsydiv ta yikh sumishei z biolohichno aktyvnymy preparatamy dlia zakhystu kartopli vid khvorob [Perspectives of the use of fungicides and their mixtures with biologically-active preparations for potato protection from diseases]. Kartopliarstvo Ukrainy - Potato growing in Ukraine, 5/6, 44-47 [in Ukrainian].

8. Andrivon, D., Lucas, J.M. \& Ellissèche, D. (2003). Development of natural late blight epidemics in pure and mixed plots of potato cultivars with different levels of partial resistance. Plant Pathol, 52(5), 586-594. DOI: 10.1046/j.1365-3059.2003.00882.x [in English].

9. Dospekhov, B.A. (1985). Metodyka polevoho opyta [Methods of field research]. Moskva : Kolos [in Russian].

10. Trybel, S.O. (2001). Metodyky vyprobuvannia $i$ zastosuvannia pestytsydiv [Methods of testing and using pesticides]. Kyiv: Svit [in Ukrainian].

Стаття надійшла до редакції журналу 28.01.2020 